\title{
Clinical Evaluation of Agnitundi Vati in the management of Gridhrasi With special reference to Sciatica
}

\author{
Research Article
}

\section{Gabhane S M1*}

1. Professor, Department of Rognidan-Vikritivigyan, Datta Meghe Ayurvedic Medical College Hospital and Research Center, Wanadongri, Nagpur.

\begin{abstract}
In the present era, Gridhrasi is the commonly occurring disease in both geriatric and middle age. It causes due to irritation of sciatic nerve. According to Ayurveda, vataprakopak nidanas i.e. depletion of dhatu and obstruction of channels are the causes of Gridhrasi. Vata plays a major role in pathogenesis of the disease but sometimes associated with kapha. Agnitundi Vati described in Sharangadharsamhita has the properties acting on both vata and kapha. To assess the efficacy of Agnitundi vati in the management of Gridhrasi, present study was undertaken in 30 patients of both types of Gridhrasi. 125- $250 \mathrm{mg}$ of Agnitundi Vati was given orally, two times daily after meal with lukewarm water for total 21 days. It showed hopeful results in subjective and objective parameters of Gridhrasi. The study shows that Agnitundi vati is effective in management of both types of Gridhrasi, but more effective in vatakaphaj Gridhrasi.
\end{abstract}

Key Words: Gridhrasi, Vataprakopak nidanas, Vata, Kapha, Agnitundi vati.

\section{Introduction}

Sciatica is characterised by constant aching painin the lumber region radiating to the buttock, calf and foot caused by irritation of the sciatic nerve. (1) It is quite a common condition with a lifetime incidence varying from $13 \%$ to $40 \%$. The consequent annual incidence of an episode of sciatica ranges from $1 \%$ to 5 $\%$. (2)

It can be compared to Gridhrasi described in ayurvedic text having pricking pain, twitching along the route of sciatic nerve. It occurs both in old and middle age. It is one of the 80 types of Nanatmaja vyadhi of vata. (3) The generalvata prakopa nidanas are nidanas of Gridhrasisuch as improper sitting posture, over exertion, over loading, trauma to lumbosacral spine, production of ama, jerky movements during travelling etc. (4) The samprapti of Gridhrasi is a complex mechanism. The vata provoked by the above-mentioned factors, either by depletion of dhatu or by the occlusion of channels, enters the emptymajjavaha srotas and leads to Gridhrasi. (5)

The cardinal features of Gridhrasi are ruk(pain), toda(pricking sensation),stabdhata(stiffness), spandana(twitching) in the buttocks, low back region radiating to thigh, knee, calf region and foot,whereas arochak (aversion to food), tandra(drowsiness), and gaurava(feeling of heaviness) come across additionally

\section{* Corresponding Author:}

\section{Gabhane S M,}

Professor, Department of Rognidan-Vikritivigyan,

Datta Meghe Ayurvedic Medical College Hospital and

Research Center, Wanadongri, Nagpur.

Email id - mungle.shilpa@gmail.com when kapha is associated with vata. (6) Due to severe pain, it creates little threat to life. Treatment of the disease includes analgesics, traction therapy and physical therapy. Surgery i.e. removal of disc herniation also recommends according to stage. This treatment reduces only leg pain and corresponding symptoms, not the back pain and the chances of recurrence are more.

Vata plays major role in the pathogenesis of the disease but most of the times associated with kapha. Alsobeing a nervine disorder, can be treated by a drug having deepana, pachana, vatashamakaand shoolaghna properties along with having action on nerves. Agnitundi vati mentioned in Sharangadhara samhita is having all the properties. (7) This drug is using being successfully to cure vatarogas. But it is need to study on scientific measures to make more use of it.

\section{Materials \& Methods \\ Objective of the study}

To evaluate the efficacy of Agnitundi Vati in the management of Gridhrasi.

\section{Source of Data}

Patients attending the OPD and IPD of the Department of Rognidan- Vikritivigyan and Dept of Kayachikitsa, Pakwasa Samanvay Rugnalaya and Dept of Rognidan- Vikritivigyan of Akhil Bhartiya Ayurved Anusandhan, Nagpur.

\section{Method of Collection}

30 participants fulfilling the diagnostic and inclusion criteria, belonging to either sex irrespective of socio-economic status and caste were selected and registered for the clinical study. Prakriti, addiction, gender, occupation of the patients was also studied. 


\section{Diagnostic criteria}

Patients were diagnosed on the basis of following clinical features

1.Patients having cardinal symptoms of Gridhrasilike Ruk, Toda,Stambha andSpandana in Sphik, Kati radiating to Prishthabhaga of Uru, Janu, Jangha and Pada. affected leg.

2.Positive straight leg raises (SLR) test in

\section{Inclusion Criteria}

1.Patients fulfilling the diagnostic criteria.

2.Patients of both sex between age group 20- 65

years.

\section{Exclusion Criteria}

1.Benign or Malignant tumour of spine, traumatic injury, Tuberculosis of vertebral column.

2.Developmental anomalies.

3.Uncontrolled diabetes mellitus,cardiovascular diseases.

4.Pregnant and Lactating women.

Laboratory Investigation (Objective Parameter)

-Routine haematological investigation- $\mathrm{Hb} \%$, TLC, DLC, ESR

-Urine for routine and microscopic examination view.

-X-ray of Lumbosacral spine - AP and Lateral

\section{Plan of Treatment}

125- $250 \mathrm{mg}$ of Agnitundi Vati wasgiven orally, two times daily after meal with lukewarm water for total 21 days. A gap of 1 day was given in between two weeks.

Weekly follow up was taken.

Agnitundi Vati was prepared in Universal Pharmacy, Nagpur.

\section{Contents of Agnitundi vati:}

Bhavana Dravya- Jambeera(Citrus Limon)

\begin{tabular}{|l|c|}
\hline Ingredients & Quantity \\
\hline Parad(Mercury) & 1 part \\
\hline Gadhak (Sulphur) & 1 part \\
\hline Vatsanabh (Aconitum ferox) & 1 part \\
\hline Haritaki (Terminalia chebula) & 1 part \\
\hline Bibhitak (Terminalia belerica) & 1 part \\
\hline Amalaki (Phyllanthus emblica) & 1 part \\
\hline Chitrak (Plumbago zeylanica) & 1part \\
\hline Jeerak (Cuminum cyminum) & 1 part \\
\hline Ajamoda (Carum Roxburghianum DC) & 1 part \\
\hline Vidanga (Emblica ribes) & 1 part \\
\hline Shunthi (Zingiber officinale Roscae) & 1 part \\
\hline Marich (Piper nigrum) & 1 part \\
\hline Pippali (Piper longum) & 1 part \\
\hline Sarji kshara & 1 part \\
\hline Yava kshara(Potasii carbons) & 1 part \\
\hline Saindhava (Sodii chloridum) & 1 part \\
\hline Sauvarchala (Unaqna sodium chloride) & 1 part \\
\hline Samudra (Sodii muras) & 1 part \\
\hline Kupeelu (Strychnos nux-vomica Linn) & 18 parts \\
\hline
\end{tabular}

\section{Assessment Criteria}

Subjective and objective parameters presented by the patients were given score and were assessed before and after every week for 3 weeks.

Gradation for Subjective parameter

Ruk (Pain)

0 : No pain

+: Painful but walks without limping

++ : Painful, walks with limping but without support

+++ : Painful, can walk only with support

++++ : Severe pain, unable to walk

Stambha (Stiffness)

0: No stiffness

+: Mild Stiffness

++ : Moderate stiffness

+++ : Severe stiffness

++++ : Very severe stiffness

Spandana (Twitching)

0 : No twitching

+ : For few minutes occasionally

++ : Daily once in a day for few minutes

+++ : Many times, in a day affecting daily routine

++++ Daily for many times severely hampering daily routine

Arochak

0 : Absent Arochak

+: Mild Arochak

++: Moderate Arochak

+++: Severe Arochak

Gaurava

0: Absent Gaurava

+: Mild Gaurava

++: ModerateGaurava

+++: Severe Gaurava

Tandra

0 : Absent Tandra

+: Mild Tandra

++: Moderate Tandra

+++ : Severe Tandra

Gradation for SLR

0: Equal to or greater than 900

+: 710 to $<900$

$++: 510-700$

$+++: 310-500$

$++++:<300$

\section{Observations and Result}

Total 30 patients of Gridhrasi were registered. Important features were as follows:

\section{Graph 1. Showing the distribution of gender in $\mathbf{3 0}$ patients of Gridhrasi}

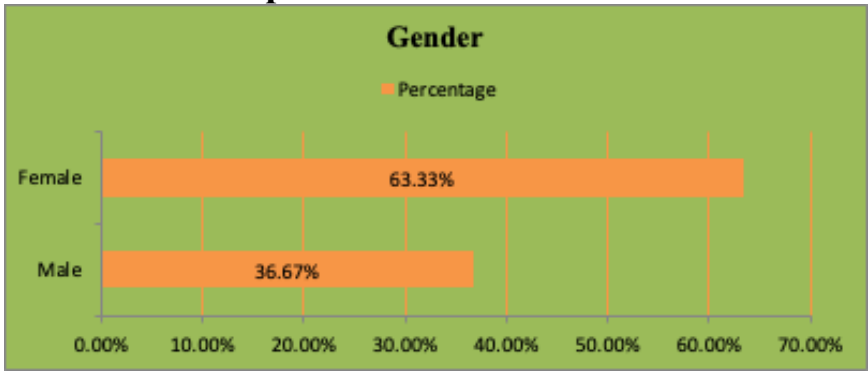

Maximum, 63.3\% were females. 
Graph 2. Showing the relation of age in 30 patients of Gridhrasi

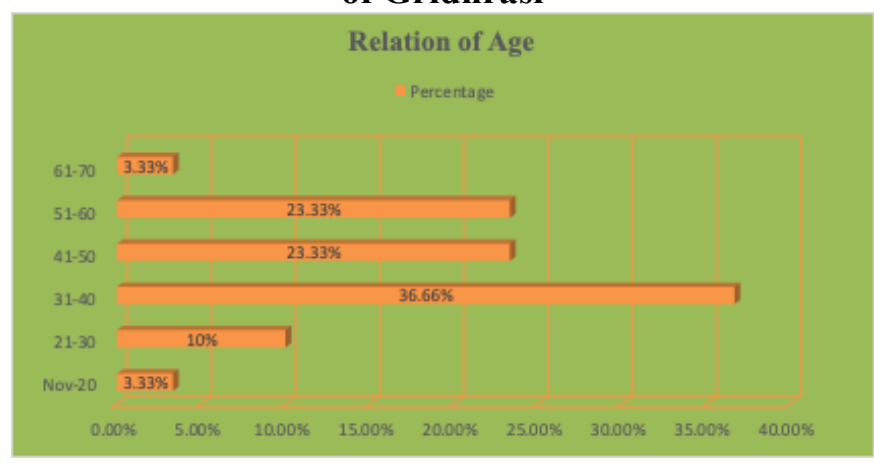

Maximum, 36.66\% were in age group $31-40$ and $86.65 \%$ were in the age group of $31-60$ years.

Graph 3. Showing the relation of occupation in 30 patients of Gridhrasi

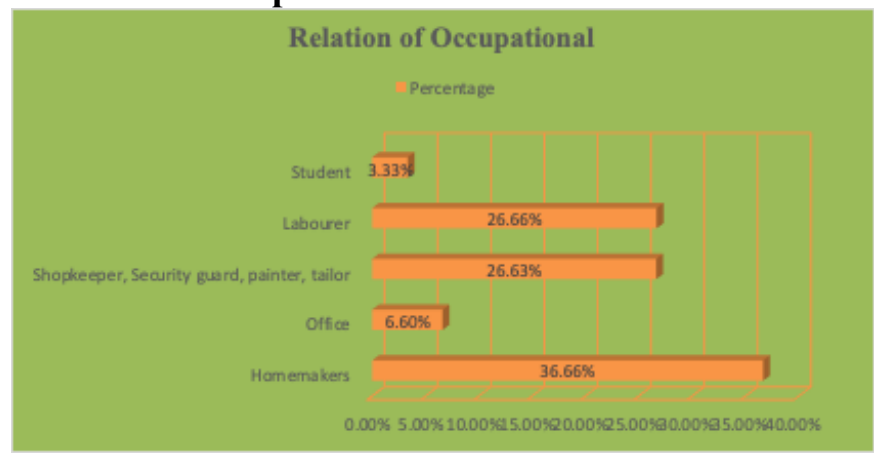

Maximum, 36.66\%were homemakers,

Graph 4. Showing the relation of Addiction in 30 patients of Gridhrasi

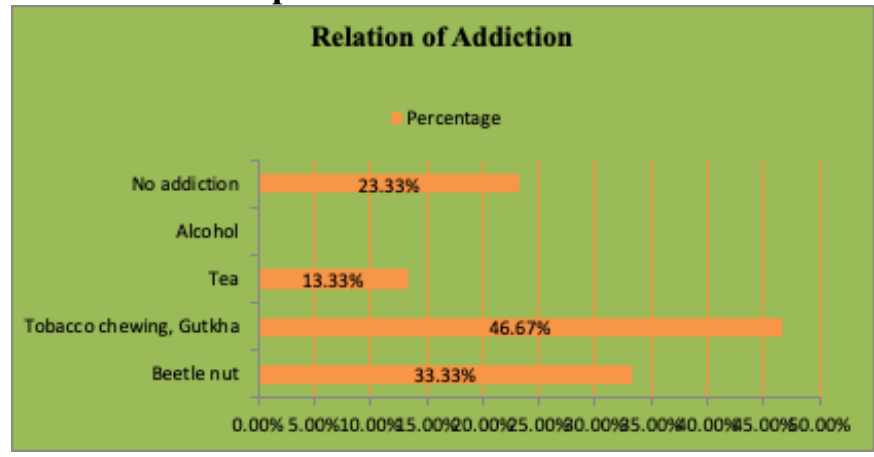

Maximum, 46.67\% were having addiction of tobacco chewing and gutkha and $33.33 \%$ having addiction of beetle nut.

Graph 5. Showing the Prakriti wise distribution in 30 patients of Gridhrasi

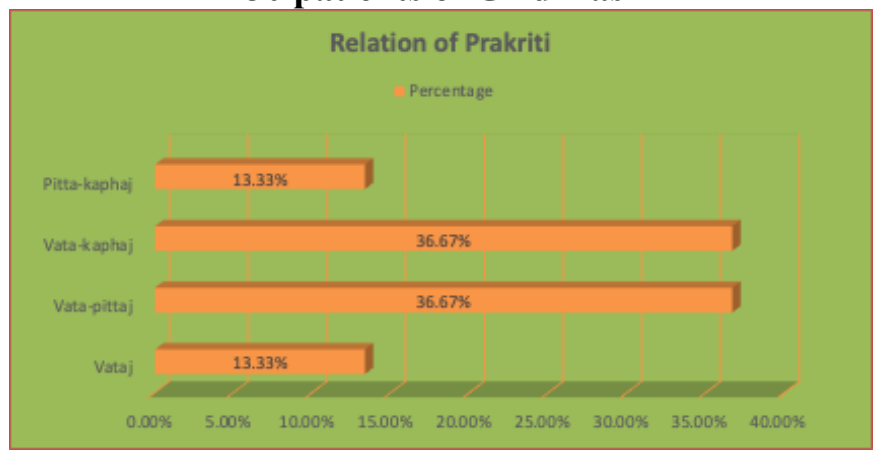

According to prakriti, $36.67 \%$ patients were of vata-kaphaj and $36.67 \%$ were of vata-pittaj prakriti.

Graph 6. Showing the relation of Agni in 30 patients of Gridhrasi

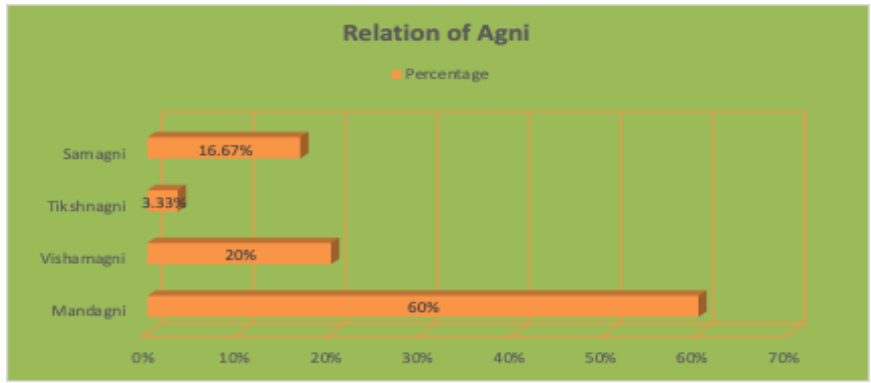

According to agni, majority of patients i.e. $60 \%$ were having mandagni.

Graph 7. Showing the type of Gridhrasi occurred in 30 patients

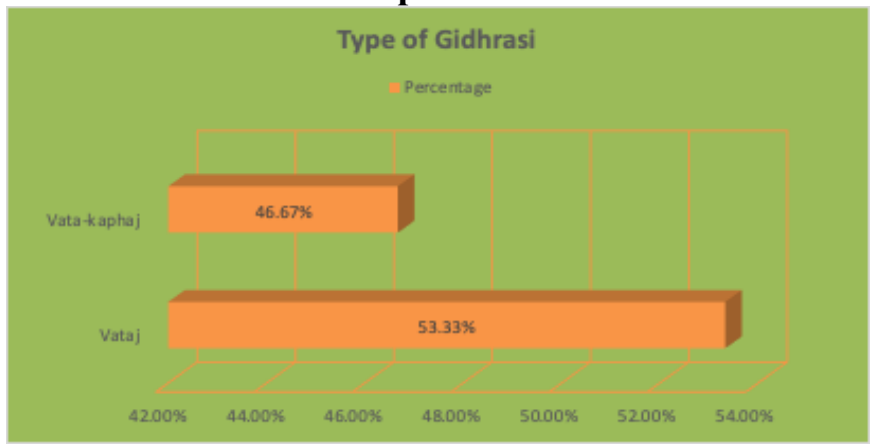

$53.33 \%$ patients were diagnosed as vataj Gridhrasi and $46.67 \%$ patients as vata-kaphaj Gridhrasi.

Graph 8. Showing the relief in Vata-kaphaja Gridhrasi

Vata-kaphaja Gridhrasi \% Relief

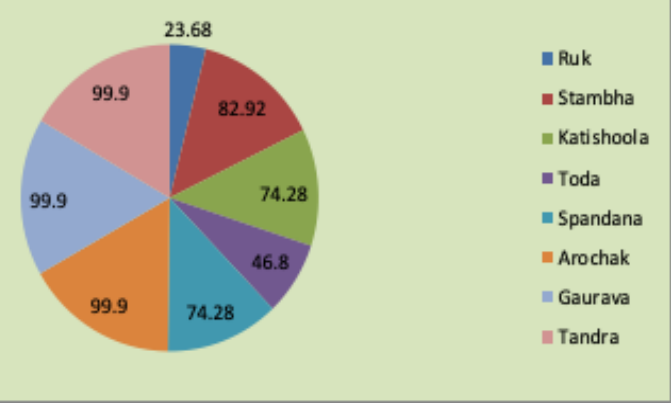

Graph 9. Showing the relief in Vataja Gridhrasi Vataja Gridhrasi \% Relief

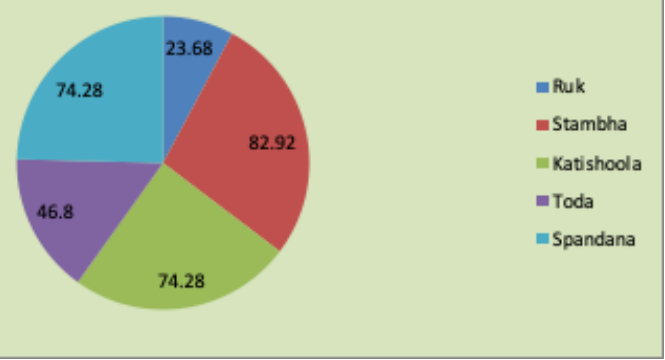


Gabhane SM et.al., Role of Agnitundi Vati in the management of Gridhrasi (Sciatica)

Table 8. Effect of treatment in sign and symptoms

\begin{tabular}{|c|c|c|c|c|}
\hline \multirow{2}{*}{ Signs \& Symptoms } & \multicolumn{2}{|c|}{ Mean } & \multirow{2}{*}{$\begin{array}{c}\% \\
\text { Relief }\end{array}$} & \multirow{2}{*}{$\begin{array}{l}\text { ' } P \text { ' } \\
\text { value }\end{array}$} \\
\hline & BT & AT & & \\
\hline$R u k$ & 2.53 & 1.93 & 23.68 & $<0.01$ \\
\hline Stambha & 1.367 & 0.233 & 82.92 & $<0.001$ \\
\hline Katishoola & 1.367 & 0.233 & 74.28 & $<0.001$ \\
\hline Toda & 1.567 & 0.833 & 46.80 & $<0.001$ \\
\hline Spandana & 0.966 & 0.066 & 74.28 & $<0.001$ \\
\hline Arochak & 0.4667 & 0 & 99.9 & $<0.001$ \\
\hline Gaurava & 0.4667 & 0 & 99.9 & $<0.001$ \\
\hline Tandra & 0.4667 & 0 & 99.9 & $<0.001$ \\
\hline SLR test Rt. leg & 1.39 & 0.42 & 69.78 & $<0.001$ \\
\hline SLR test Lt. leg & 1.27 & 0.55 & 56.69 & $<0.001$ \\
\hline
\end{tabular}

BT- Before Treatment AT- After Treatment

Agnitundi Vati was found more significant $74.28 \%$ in (Katishoola) pain, $82.92 \%$ in (Stambha) stiffness, $46.80 \%$ in (Toda) pricking sensation, $74.28 \%$ in (Spandana) twitching, 99.9\% relief was found associated symptoms such as arochak, gaurava, tandra. patients.

The symptom sphik prarambhata found in $60 \%$

Cardinal symptom of ruk, toda and positive SLR test were found in all patients.

leg.

$76.67 \%$ patients were having symptoms in right $73.80 \%$.

The drug is found highly effective in SLR test

\section{Criteria for assessing the effect of therapy}

The effect of therapy was evaluated on the basis of improvement in sign and symptoms. Statistical analysis, means, standard deviations and standard errors and percentages were calculated. Kruskal Wallis Test with Dunn's Multiple Comparison Test was applied for assessing sign and symptoms. Mann Whitney's Test was applied for assessing laboratory investigations.

The obtained results were interpreted as:

$$
\begin{aligned}
& P>0.05 \text { - Not significant } \\
& P<0.05 \text { - Significant } \\
& P<0.01 \text { - More significant } \\
& P<0.001 \text {-Highly significant }
\end{aligned}
$$

The obtained results were classified as:

Marked improvement: $75 \%-100 \%$ relief

Moderate improvement: $51 \%$ - $<75 \%$ relief

Mild improvement: $25 \%-50 \%$ relief

Unchanged $:<25 \%$ relief

\section{Discussion}

The maximum number of patients was present between 31-40 age groups. In vataprakriti individuals vatavriddii starts at this age. As age increases, the form and composition of the individual structure may increase the risk of injury due to decrease in hydration of inter vertebral disc. (8) This decrease in hydration may be due to rukshata which increases as a result of vatavriddhi. Prevalence commonly found in this age group. females. (9)

Sex- the higher incidence of disease occurred in

There was higher incidence of sciatica in homemakers. Working constantly with improper posture for long duration during household work, lack of exercise; irregular food habits and cold exposure are the contributing factors. Labourer also show comparatively high incidence because of heavy work they do. (10)

A high proportion of patients were having vatapittaj and vatakaphaj prakriti suggesting that vata has major role in the manifestation of sciatica

Maximum patients were having addiction of beetle nut, tobacco chewing and gutkha. These factors lower the bone mineral density causing osteoporosis. It causes osteoporotic vertebral fractures compressing the sciatica nerve thereby responsible for nervine damage. (11) As beetle nut is kashaya in rasa, it vitiates vata.(12)

\section{Effect of therapy}

Kupeelu (Strychnos nux-vomica Linn.) is the major content of drug which is more effective in nervine disorders. It improves stimulatory function of $v a t a$, when function of vata decreases due to association with kapha.

All contents of Agnitundi vati are deepana, pachana, vatashamaka and shoolaghna in properties. Due to its ushna virya it normalises the function of apana and vyanavayu. (13)

\section{Conclusion}

The drug Agnitundi vati showed good results in both types of Gridhrasi, but better relief seen in vatakaphaj Gridhrasi. Ingredients of this vati having deepana, Amapachana, vatashamaka and shoolaghna properties. it improves agni by digesting ama which is the main factor in vatakaphaj Gridhrasi. In this way relieves generalised symptoms such as aruchi, gaurava and tandra. This drug works at the root level of samprapti and minimizes chances of recurrence.

\section{References}

1. Stuart H. Ralston, Ian D. Penman, Mark WJ. Strachan, Richard P. Hobson, Davidson's Principle and Practice of Medicine. 23ed. Elsevier, 1135p.

2. Stafford MA, Peng P, Hill DA, Sciatica: a review of history, epidemiology, pathogenesis, and the role of epidural steroid injection in management. BJA. 99(4), 2007; 461-473p.

3. Pandey K, Chaturvedi G. Chakrapani Tika, Achaarya Charaka and Dhrudhabala, Chaukhambha Bharati Academy,Varanasi, Edition 2003; 399p.

4. Pandey K, Chaturvedi G. Chakrapani Tika, Achaarya Charaka and Dhrudhabala, Chaukhambha Bharati Academy,Varanasi, Edition 1998; 779p. 
5. Gupta K. A, Vagbhata, Asthanga Hridaya Chaukamba Sanskrit Sansthan, Varanasi, 13 ed 2000; 276p.

6. Pandey K, Chaturvedi G. Chakrapani Tika, Achaarya Charaka and Dhrudhabala, Chaukhambha Bharati Academy, Varanasi, Edition 1998, 2(56); 787p.

7. Tripathi B. Sarangadhara-Samhita.Acharya Sarangadhara, Chaukhambha Surbharati Prakashan, Varanasi. 3rd ed 1998; 311p.

8. Ferquson SJ, Steffen T, Biomechanics of the aging spine. October 12, 2003.

9. Rahman S, Hassani K,Heliovaara M, Solovieva S, Amiri S, Lallukka T, Burdorf A, Pursiainen KH, Juntura EV. Risk factors for Low Back Pain:A Population- Based Longitudinal Study.2018; https:// doi.org/10.1002/acr.23710.
10. Parreira P, Maher CG, Steffens D, Hancock MJ, Ferreira ML, Risk factors for low back pain and sciatica: an umbrella view. 2018; 18(9); 1715-1721p.

11. Syed SA, Baig S, Qamar J, Hasan D, Syed AA. Osteoporosis in males and its association with tobacco; smokers and chewers; European Journal of Biotechnology and Bioscience.

12. Pandey K, Chaturvedi G. Chakrapani Tika, Achaarya Charaka and Dhrudhabala, Chaukhambha Bharati Academy,Varanasi,Edition 2003, 1 (43),507p.

13. Sushrut Samhita,Aacharya Sushrut,Ayurved Tattva Sandipika tika, Chaukhamba Sanskrit SansthanVaranasi, ed. 2007; 151p. 